\title{
USE OF VERMICOMPOSTING BIOTECHNOLOGY FOR RECYCLING FLY ASH AS A SOURCE OF PLANT NUTRIENTS
}

\author{
G.N.Chattopadhyay \\ Gourab Roy \\ Wasim Iftikar \\ Soil Testing Laboratory \\ Institute of Agriculture \\ Visva-Bharati University \\ Sriniketan-731236, West Bengal, India
}

\begin{abstract}
Large scale generation of fly ash from increasing numbers of coal fired plants is now emerging as a global environmental threat. To combat the situation, emphasis is being given on recycling of this waste material for various productive purposes. Since fly ash contains many plant nutrients in appreciable amount, it's re-use as a source of these nutrients forms an important component of such efforts. However, the major problem associated with supply of plant nutrients through fly ash is the low availability of most of the nutrients in this material despite their good occurrence in total amount. This behavior is attributed to inert nature of this burnt material. Since vermicomposting helps in accelerated degradation of various kinds of wastes through earthworm gut microorganisms, we assessed the possibility of enhancing the availability of different plant nutrients in fly ash through this biotechnology. The results of a series of yard as well as on-farm studies showed that introduction of epigeic earthworms in mixtures of fly ash and organic wastes helped to stabilize the organic matter and enhance the microbiological activity in the substrates. These, in turn, helped to improve the availability of three major nutrients viz. N, P and K in the composted materials. It was further observed that substantial shares for such increments came from degradation of fly ash. Onfarm trials showed use of vermicomposted fly ash to be able to compensate the application rates of fossil fuel based chemical fertilizers to $40-50 \%$ without compromising the yield of the crops. Status of different soil health attributes were also found to be in acceptable ranges under these treatments. A protocol for vermicomposting of fly ash, developed through systematic studies on screening of suitable earthworm species, maintenance of optimum composting condition, use of varying kinds of organic wastes etc, has been discussed.
\end{abstract}

\section{KEY WORDS}

Fly ash recycling; Vermicomposting; Nutrient availability

https://doi.org/10.15626/Eco-Tech.2010.055 


\section{INTRODUCTION1}

Fly ash (FA) is the residue of combustion in different coal fired plants that enters the flue gas stream. With the consistently increasing numbers of coal-fired plants, large-scale generation of FA is presenting an acute waste disposal problem in different parts of the world [2]. Gradually deteriorating quality of coal due to extensive exploitation of mines is likely to aggravate this situation further, if clean coal technologies are not adopted widely. Generation of such huge amount of coal residues presents several problems, the most serious ones being environmental hazard and requirement of large areas for disposal of this waste material. Hence, the urgent and imperative needs to overcome these problems, not only through safe disposal but also through gainful recycling of these materials, cannot probably be over emphasized [10]. The seriousness of the problem has been recognized at global levels and various possibilities of effective disposal and re-use of FA are being explored in different countries. Among these, application of FA for agricultural cultivation is a comparatively less attended field but has been showing promising results, especially for rejuvenating low fertile or wastelands [22, 34, 20]. This benefit may be attributed primarily to alkaline nature of most of the FA, which may be used to improve the $\mathrm{pH}$ levels of acid soils, and also to its total content of different nutrient elements in varying concentrations [1]. However, the major problems associated with plant nutrition from FA are its inert nature owing to very poor microbiological activity in such material and the low occurrence of most of the nutrient elements in available forms [10]. The possibilities of improving the status of availability of different plant nutrients in fly ash through encouragement of microbiological activity for enhancing its acceptability in agricultural cultivation has been discussed in this communication with special reference to vermicomposting biotechnology.

\section{USE OF FLY ASH IN AGRICULTURE}

Fly ash contains almost all the plant nutrients, excepting nitrogen and organic carbon, in considerable amount. Hence it has been thought by many workers that this material may be used for several agriculture related activities as a source or carrier of plant nutrients [27, 38]. Good amount of studies have been carried out in agriculture and forestry sectors to assess the effect of fly ash as a source of plant nutrients which have shown that these ashes have some beneficial properties which can be utilized for agronomic purposes. Positive effects of FA application on yield levels of alfalfa, barley, bermuda grass, white clover etc. have been reported by different workers $[25,15]$. .Total occurrences of many nutrients have also been reported to be comparatively higher than what are generally observed in arable soils (Table-1) and use of FA has been suggested for increasing the nutrient status of such soils [20].

In general, FA has been observed to promote better growth or yield of different crops up to a certain level of application of this material to soil and the beneficial effects tend to decline beyond that dose. These effects are, however, likely to vary from one crop to other and also in different soils. Use of coal ash on growth and nutritional status of spinach in two kinds of soils viz. black cotton and alluvial using various soil: ash mixtures has shown the shoot length, chlorophyll concentration and carbohydrate content of the plants to increase up to $25 \%$ of ash application [21]. However, most of the studies carried out on utilization of FA in 
agriculture deal with yields_of different crops due to application of various doses of ash and limited work have been carried out to provide scientific or technical backgrounds for such results.

Table-1 General characteristics of Indian fly ash and arable soils

$\begin{array}{lcc}\text { Properties } & \text { Fly Ash } & \text { Soil } \\ \text { B.D. }\left(\mathrm{g} \mathrm{cm}^{-3}\right) & <1.0 & 1.33 \\ \text { W.H.C (\%) } & 35-40 & <20 \\ \text { Porosity (\%) } & 50-60 & <25 \\ \text { P (\%) } & 0.004-0.8 & 0.005-0.2 \\ \mathrm{~K}(\%) & 0.19-3.0 & 0.04-3.0 \\ \mathrm{~S}(\%) & 0.1-1.5 & 0.01-0.2 \\ \mathrm{Fe}\left(\mathrm{mg} \mathrm{kg}^{-1}\right) & 36-133 & 10-300 \\ \mathrm{Zn}\left(\mathrm{mg} \mathrm{kg}^{-1}\right) & 14-1000 & 2-100 \\ \mathrm{Cu}\left(\mathrm{mg} \mathrm{kg}^{-1}\right) & 1-26 & 0.7-40 \\ \mathrm{Mn}\left(\mathrm{mg} \mathrm{kg}^{-1}\right) & 100-3000 & 100-4000 \\ \mathrm{~B}\left(\mathrm{mg} \mathrm{kg}^{-1}\right) & 46-618 & 0.1-40\end{array}$

Source : [20]

\section{AVAILABILITY OF PLANT NUTRIENTS IN FLY ASH}

In spite of these positive effects of fly ash application in agriculture, availability of adequate amount of different nutrients in such material has long been considered as a major constraint. Most of the plant nutrients present in FA do not remain in bio-available forms despite their total occurrence in considerably higher concentrations and take a long time to be transformed to available forms after their application. This behavior has been attributed to inert nature of FA due to restricted microbiological activity in such materials [9].Under this context,it has been suggested that simultaneous use of FA and organic matter might be an effective proposition for improving this property. It was conceived that use of organic matter would help to extract more nutrient elements to available forms through acid extraction in one hand and encourage microbial degradation of FA to more soluble forms on the other. In fact, many of the significant beneficial effects of FA application in agriculture have been observed when 
the ashes were incorporated with organic materials [11,32]. Field experiment on use of coal ash in different combinations with organic manure and chemical fertilizers for augmenting crop production and soil productivity in rice based cropping systems has shown increased grain yield in case of wet season rice owing to application of FA in combination with organic materials and chemical fertilizers [24]. The physico-chemical properties of the soils also improved in terms of decrease in bulk density, increase in $\mathrm{pH}$, organic carbon and available nutrients viz. $\mathrm{N}, \mathrm{P}, \mathrm{K}, \mathrm{Ca}, \mathrm{Mg}, \mathrm{Zn}, \mathrm{Cu}$ and $\mathrm{Co}$. Further, there was improvement in microbial activity under the integrated use of FA and organic materials. Another set of elaborate field trials to assess the effects of different organic and industrial wastes in improving productivity of acid lateritic soil under rice-groundnut cropping system also showed integrated use of FA and organic wastes to be more effective for obtaining grain and pod yields of rice and groundnut [18].

All these studies indicate that in spite of containing many of the nutrients in high amount, FA cannot provide sufficient amount of plant nutrition through lone application of this material. Most of these nutrient elements in FA remain largely in insoluble forms which are not readily available to plants and may become accessible to them only after due transformation $[20,10]$. Hence, for increasing acceptability of FA as a source of plant nutrients, the availability of the nutrients in FA needs to be improved substantially. Encouragement of microbial activity for promoting biological as well as chemical degradation of FA and consequent release of various nutrients to soluble form may be considered to be an effective proposition in this regard. Important roles of different microorganisms in development of soils from inert parent materials through various biochemical reactions resulting from decomposition of organic matter especially formation of different acids that dissolve and extract various nutrients from insoluble forms have been discussed by different workers [6, 23]. Similar activities may appear to be useful for improving available nutrient status of FA too.

Another major problem associated with FA is poor occurrence as well as activity of different microorganisms to encourage release of different nutrients from this material, as have been reported by [28] and others. Several short-term studies under yard conditions have revealed that FA application may reduce the microbial and also enzymatic activities in the soils [40, 22]. Reduction in nitrification potential in FA amended soils under laboratory condition has also been reported [7, 14]. Such behaviors of soil microorganisms may largely be attributed to poor occurrence of organic matter in FA because of the fact that organic matter controls the growth and behavior of most of the microorganisms in any substrate. On the other hand, [34] reported some enzymatic activities and microbial $\mathrm{N}$ cycling functions to increase in FA added soils during a period of 20 months. It has been opined that gradual leaching of soluble salts and trace elements over time helped to ameliorate any initial toxicities of FA allowing plants and microorganisms to respond positively to improved soil conditions. However, the workers also stated that because of increased crop yields in FA amended soils, plant biomass in the soils increased and suggested that this increment in soil organic matter might have eventually enhanced microbial activities in FA treated soils. Such beneficial effects of organic matter on microbial activity and population of FA amended soils have been reported by workers like [22] also. They have categorically shown that the populations of different microorganisms 
like bacteria, actinomycetes and fungi increased considerably due to co-application of FA and sewage sludge in soils as against use of FA alone. Similar benefits were recorded for enzymatic activities also.

All these studies lead to the fact that for increasing the nutrient supplying capability of FA, the microbiological activity in this material need to be improved substantially. Since organic matter provides food and energy to different heterotrophic microorganisms and can extract various nutrients into soluble forms from different insoluble minerals through release of some organic acids [29], simultaneous use of FA and organic materials is likely to emerge as an effective proposition for increasing the efficiency of FA. Countries like India, which are situated under tropical climatic conditions, have vast areas of soils with low to very low organic carbon content. Simultaneous use of organic materials and FA is likely to result in some beneficial effects on such soil health, which is difficult to achieve through FA alone. However, in view of the escalating quantum of FA generation and also restricted availability of commonly used organic manures, exploration of the possibilities of using the huge resources of different kinds of organic wastes in the country for this purpose appears to be imperative [10]. This approach will not only improve the possibility of recycling FA as a source of plant nutrients but will also help in simultaneous abatement of environmental pollution created by these organic waste materials.

\section{POSSIBILITIES OF RECYCLING FA THROUGH VERMICOMPOSTING}

In view of the positive effects of application of FA along with organic materials, the potentials for recycling huge resources of both FA and different organic wastes have come into limelight. Simultaneous use of these organic wastes and FA will not only help to extract more amount of plant nutrients into available forms from insoluble fractions in FA as discussed earlier but also will help to enrich the material with organic matter for improving the soil health. However, the major problem of recycling these waste materials in agriculture is that, these organic materials cannot be applied in agricultural fields unless they are composted properly. Since most of these wastes contain various degradation resistant components, composting of these organic materials often becomes very difficult. For simultaneous recycling of FA and organic wastes, therefore, adoption of an efficient composting method appeared to be necessary.

Among different methods of composting of organic materials, vermicomposting biotechnology is recently emerging as an important one owing to simplicity as well as high efficiency of this technology in producing better quality compost, as compared to traditional methods of composting [17]. Epigeic earthworms, which live on the surface of the soils and feed on organic debris [12], harbor rich concentrations of different kinds of microorganisms, enzymes etc. in their intestines [35]. The organic materials excreted by these earthworms in half digested forms, contain these microorganisms and enzymes in high concentrations, which help in rapid aerobic decomposition of these excreted half digested organic materials resulting in the production of good quality compost in lesser period of time along with multiplication of 
different beneficial microorganisms in these compost materials [8]. In view of this efficiency of vermicomposting biotechnology in decomposing different kinds of organic wastes, some studies have been carried out in the Soil Testing Laboratory of Institute of Agriculture, VisvaBharati University, India to assess the efficiency of this technology in encouraging plant nutrition through FA. These investigations have yielded highly encouraging results. The studies showed the occurrence of different microorganisms viz. bacteria, actinomycetes and fungi to increase considerably in the FA: organic waste system on vermicomposting (Figure1). It has been suggested that this behavior helped to encourage the degradation of FA during vermicomposting and promote release of nutrients to available forms [31].

These results also support the observations of some yard studies carried out in this laboratory to assess the effects of incubating earthworm Eisenia fetida in different mixtures of FA and cow dung. It was found that this technology helped to maintain higher amount of plant nutrients in available form in the mixtures (figure-2). It was further observed that for these increments in nutrient availability, FA contributed a good share [3, 4].

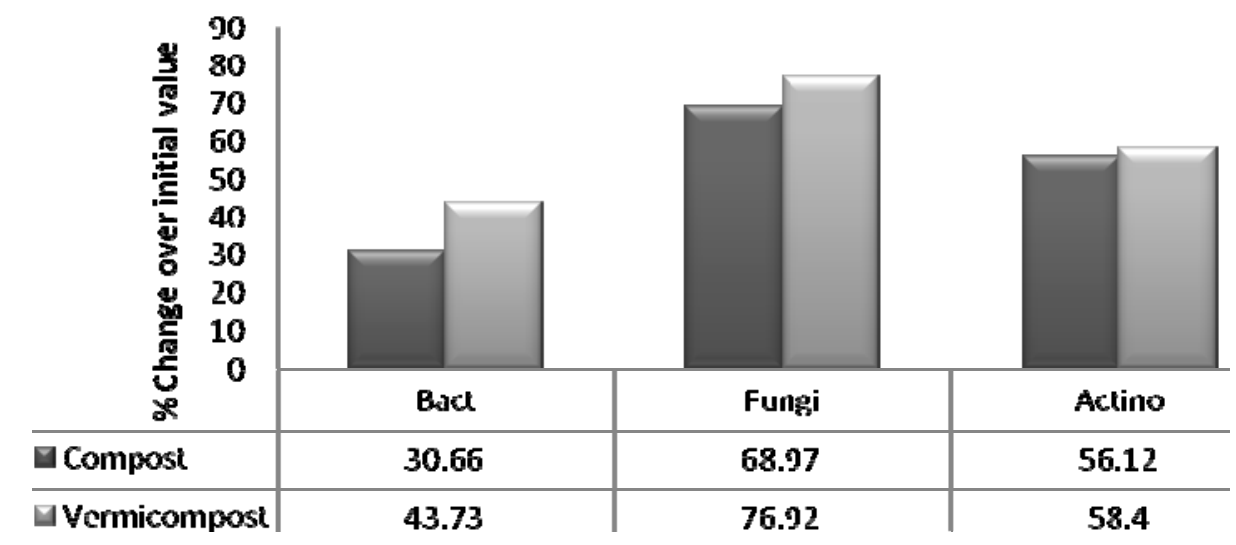

Figure 1. Changes in occurrences of different microorganisms in FA: organic waste system due to composting and vermicomposting

The results further indicated that during the process of vermicomposting, the microbial organisms involved in the composting process not only decomposed the organic components of the mixture, but also could degrade the FA to a considerable extent and bring a part of insoluble nutrients of fly ash into more available form. As an evidence to this hypothesis, the workers $[3,4]$ showed that the concentrations of nitrogen fixing and phosphorous solubilising bacteria increased considerably in different organic-ash mixtures on vermicomposting (Table2).

Table-2: Average occurrence (nos. $\times 10^{8} \mathrm{~g}^{-1}$ ) of nitrogen fixing bacteria (NFB) and phosphate solubilising bacteria (PSB) in different treatment combinations after 50 days of incubation with and without earthworm 


\section{Treatments}

NFB

PSB

$\begin{array}{ccccc} & \mathbf{E} & \mathbf{E}_{\mathbf{0}} & \mathbf{E} & \mathbf{E}_{\mathbf{0}} \\ \mathrm{FA}+\mathrm{CD}(1: 1) & 22.00 & 0.02 & 78.80 & 0.12 \\ \mathrm{FA}+\mathrm{CD}(1: 3) & 1.05 & 0.85 & 4.60 & 0.014 \\ \mathrm{FA}+\mathrm{CD}(3: 1) & 3.15 & 2.63 & 7.50 & 0.068\end{array}$

$\mathrm{E}=$ with earthworm, $\mathrm{E}_{0}=$ without earthworm

Source: $[3,4]$

In many cases, occurrences of some heavy metals are considered to be a matter of concern for using FA in agriculture [26, 36]. It was interesting to observe that the concentrations of some heavy metals viz. $\mathrm{Cr}, \mathrm{Cd}$ and $\mathrm{Pb}$ declined considerably in the vermicomposted organic-FA mixtures [5]. This behaviour was attributed to formation of metallothionein isoforms in earthworms due to exposure to these metals $[5,13,30]$. Since the earthworms are isolated from the vermicomposted FA prior to the application in fields, use of this technology is likely to reduce the problem of heavy metal toxicity in FA to a considerable extent. Similar effects of using vermicomposting biotechnology on recycling of FA have been reported by other workers also [33, 39].

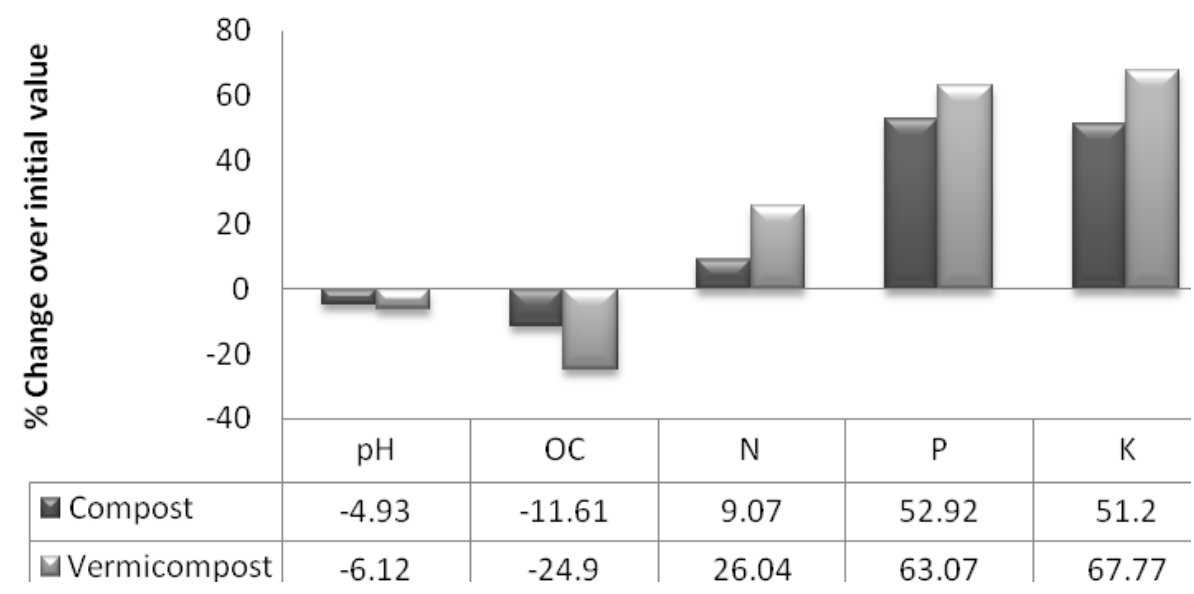

Figure 2. Changes in availability of different plant nutrients in FA: organic waste systems after composting and Vermicomposting

These beneficial effects of vermicomposting of fly ash have been observed in field levels also. Use of vermicomposted fly ash resulted in substantial yield increments in case of potato [10]. It has been shown that integration of vermicomposted FA with mineral fertilizers played 
a very important role in producing potato in red and lateritic soils and helped to reduce the requirement of chemical fertilization to nearly $40 \%$ level (table-3).

Table-3: Potato yields $\left(t h^{-1}\right)$ under different treatments using vermicomposted $F A$ in regularly cultivated and previously fallow land under a red-lateritic soil zone of West Bengal, India.

Treatments

Yield (t ha $\left.{ }^{-1}\right)$

(In regularly cultivated land )

21.95

30.12

27.42

22.42

25.48

1.53
Yield (t ha $\left.{ }^{-1}\right)$

(In previously un-used land)

26.15

21.30

0.99

$\mathrm{NPK}_{100}=100 \%$ recommended NPK fertilizer

$\mathrm{NPK}_{80}=80 \%$ recommended NPK fertilizer

$\mathrm{NPK}_{60}=60 \%$ recommended NPK fertilizer

FYM = Farm yard manure; VC=Vermicomposted FA (both added @ $5 \mathrm{t} \mathrm{ha}^{-1}$ )

Source: [10] 


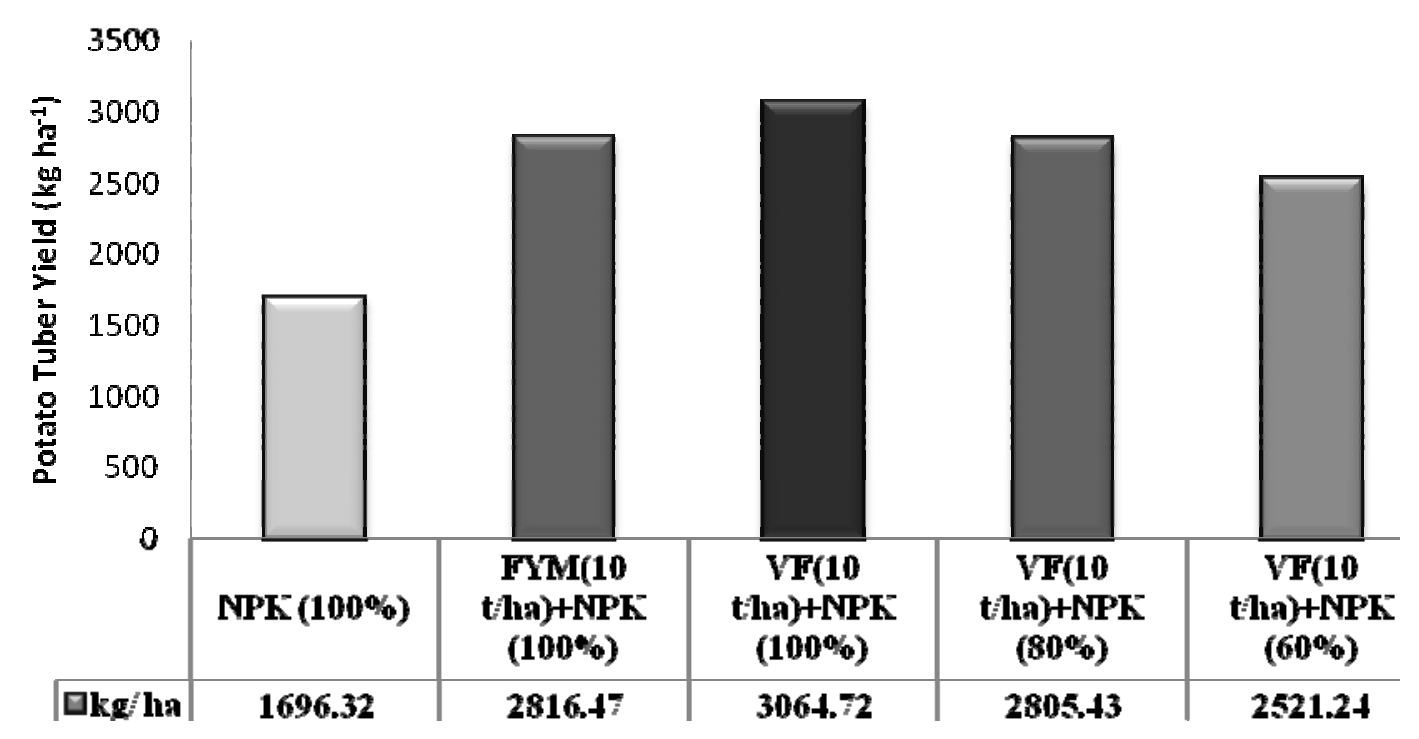

NPK 100,80 and $60 \%=\%$ of recommended NPK fertilization,FYM= farm yard manure, $\mathrm{VF}=$ vermicomposted fly ash

Figure 3. Effect of vermicomposted FA on yield of potato under integrated nutrient management

Similar observations have also been made in other studies on effect of vermicomposted FA on integrated nutrient management of potato [16], it has been found that use of vermicomposted FA compared well with farmyard manure and produced comparable yields even after considerable reduction in the dose of chemical fertilizers (figure - 3).

\section{PROTOCOL FOR PREPARATION OF VERMICOMPOSTED FA}

Based on the knowledge accrued so far, a protocol for production of vermicomposted FA has primarily been prepared at the Institute of Agriculture, Visva-Bharati University under a Fly Ash Unit, Department of Science and Technology, Govt. of India supported program. The protocol may be summarized as follows:

i) Mixing of organic wastes with fly ash: Use of FA and easily degradable organic wastes at 1:1 ratio has shown best results.

ii) Primary curing of the substrates: After mixing, the mixtures need to be kept under moist condition for 8-10 days or till the period thermophillic stage persists.

iii) Incubation of earthworms: Generally, epigeic earthworms, which live on the surface layers, are to be used for this purpose. Among various species of such earthworm, Eisenia foetida has been observed to exhibit highest efficiency in terms of survival as well as capability of degrading the wastes. 
iv) Maintaining optimum environmental conditions: Vermicomposting is an aerobic microbilogical process. Hence, maintenance of proper levels of moisture and aeration in the composting system appears to be very important. Studies carried out by the authors have shown a moisture range of $40-50 \%$ and maintaining an aerobic condition through frequent turning of the substrates to be conducive for optimization of microbial degradation. The rate of such composting is maximum under $25-35^{\circ} \mathrm{C}$ range.

v) Additional microbial management: Since FA contains very little amount of nitrogen, inoculation of nitrogen fixing bacteria before release of earthworms has shown promising results. Similarly, use of phosphate solubilizing bacteria also helps to increase the availability of phosphorus in this composted material.

vi) Harvest of the product: Under optimum condition, the vermicomposted fly ash should be ready within 50-60 days of incubation with earthworms. At this stage, the materials are air dried and sieved. The composted materials pass through the sieve and the earthworms are trapped above the sieve. The earthworms are then collected and re-used for next set of vermicomposting.

\section{CONCLUSION}

So long, vermicomposting biotechnology has been used for recycling different kinds of organic wastes only. The studies discussed in this communication indicate that vermicomposting may also be considered as an effective tool for facilitating the re-use of inorganic wastes like fly ash in agriculture. Good amount of insoluble nutrients of FA may be transformed into bioavailable forms through this process. However, this is a new field of study and more information need to be collected on different aspects of this biotechnology

\section{ACKNOWLEDGEMENT}

Authors are thankful to Fly Ash Unit, Department of Science and Technology, Govt. of India for supporting the study.

\section{REFERENCES}

[1] Adriano, D.C., Page, A. L., Elseewi, A. A., Chang, A. C. and Straughan, I. 1980. Utilisation and Disposal of fly ash and other coal residue in terrestrial ecosystems - a review. J. Environ. Qual.9: 333-334.

[2] Bhattacharya,S.S. and Chattopadhyay, G.N. 2001 Vermicomposting as a tool for increasing availability of nutrients in fly ash. In Agricultu ral Application of Fly Ash. Proc. II Nat. Sem. on Use of Fly Ash inAgriculture. Annamalai University, Annamalainagar, India.pp.128-132.

[3] Bhattacharya, S.S. and Chattopadhyay, G.N., 2002. Increasing bioavailability of phosphorous from fly ash through vermicomposting. J. Environ. Qual.31: 2116-2119. 
[4] Bhattacharya, S.S. and Chattopadhyay, G.N., 2004. Transformation of nitrogen during vermicomposting in fly ash. Waste Management \& Research 22(6):488-491.

[5] Bhattacharya, S.S. and Chattopadhyay, G.N., 2006. Effect of vermicomposting on the transformation of some trace elements in fly ash.Nutr.Cycl.Agroecosyst.75:223-231.

[6] Brady, Nyle, C. 1980. Nature and Properties of Soils. Eurasia Publ. House (P) Ltd. New Delhi. P. 339.

[7] Cervelli, S.G., Petruzzelli, A. Perna and Menicaglis, R.1986. Soil nitrogen and fly ash utilization : a laboratory investigation. Agrochemica $30: 27-33$.

[8] Chattopadhyay, G.N. 2004. Vermicomposting as a biotechnological tool for recycling organic wastes ,In:T.K.Ghosh,T.Chakrabarti and G. Tripathi (Ed.) .Biotechnology in Environmental Management. Vol I. A.P.H Publishing Corporation, New Delhi, pp-135-145.

[9] Chattopadhyay, G.N. and Bhattacharya, S.S. 2000. Possibility of increasing available nutrient status of fly ash through vermicomposting. Proc. $2^{\text {nd }}$ Int. Conf. on Fly Ash Disposal and Utilisation, New Delhi.Vol-2. Sec. IX. pp. 14-16.

[10] Chattopadhyay, G.N. and Bhattacharya, S.S. 2010. Use of Coal Ash in Agriculture. Bull.1. Coal Ash Institute of India. Kolkata, India.

[11] Christy, N.M.P. and Raghupathy,B. 2001 Effwect of lignite fly ash in an integrated nutrient management of rice cv ADT 38 on magnesium content and uptake in backfield areas of Neyveli open cast mines. In : Agricultural application of fly ash. Proc. $2^{\text {nd }}$ Nat. Sem. on Use of Fly Ash in Agriculture. Annamalai University, Annamalainagar.India pp. 125-127.

[12] Edwards, C.A. and Lofty, J.R. 1972. Biology of Earthworms.Chapman and Hall, London.

[13] Furst, A. and Nguyen, Q. 1989. Cadmium induced metallothionein in earthworms (Lumbricus terrestris). Biol. Trace Elem. Res. 21 : 81-85.

[14] Garau, M. A., Dalmau, J.L. and Felipo, M.T. 1991. Nitrogen mineralization in soil amended with sewage sludge and fly ash. Biol. Fertil. Soils. 12 : 199-201.

[15] Hill, M.F. and Lamp, C.A. 1980. Use of pulverized fuel ash from Victorian brown coal ash as a source of nutrients for a pasture secies. Australian J.Exp.Agric. Anim. Husb., 20: 337384.

[16] Iftikar, Wasim; Roy, Gourab and Chattopadhyay, G.N. MS. Integration of vermicomposted fly ash in nutrient management of potato in a red and lateritic soil. Personal communication.

[17]Kale, Radha, D. 1993. Earthworms: The biological tools for healthy and productive soils. Congress on Traditional Sci. Tech. of India. IIT, Bombay.

[18] Karmakar, S., Mitra, B.N. and Ghosh, B.C. 1997. $1^{\text {st }}$ All India Peoples Technology Congress, Calcutta,India. 
[19] Kumar, V.; Goswami, G. and Zacharia, K.A.1999. Fly ash: its influence on soil properties. Workshop ,Indian Society of Soil Science, 18-21 ${ }^{\text {st }}$ October, 1999, Calcutta.

[20] Kumar, V.; Zacharia, K.A. and Goswami, G.2000. Fly ash use in Agriculture : a perspective. In Proc of $2^{\text {nd }}$ Int. Conf. on fly ash disposal and utilisation (Fly Ash II), 2-4 Feb, 2000, New Delhi, India, pp-IX-1-13.

[21] Kumari, K. and Dubey, P.S. 2003. Effect of fly ash on growth and nutritional status of spinach. In : Proc. of $3^{\text {rd }}$ Int. Conf. on Fly Ash Disposal and Utilisation(Fly Ash II), 19-21 Feb, 2003, New Delhi, India, pp-VII-54-60.

[22] McCarty, G. W. R.; Siddarmappa, R. J. ; Wright, E. E. and Gao, G. 1994. Evaluation of coal combustion byproducts as soil liming materials: Their influence on soil $\mathrm{pH}$ and enzyme activities. Biol. Fertil. Soils.17: 147-172.

[23] Miller Raymond,W. and Donahue Roy, L.1992. Soils - An Introduction to Soils and Plant Growth. Prentice Hall of India Pvt. Ltd. New Delhi. pp- 768.

[24] Mitra,B.N. ;Ghosh,B.C. ;Karmakar, S. ;George,J. ; Rautray,S.K. and Basu,S. 2000. Utilization of industrial solid wastes in augmenting crop production and soil productivity : B. B. Jana, R. D. Banerjee, B.Guterstam and J. Heeb. (Eds.). Waste Recycling And Resource Management in the Developing World. pp. 185-195.

[25] Mulford, F. R. and Martens, D.C. 1971. Response of alfalfa to boron in fly ash. Soil Sc. Soc. Am. Proc. 35: 296-300.

[26] Nass, M. M.; Lexmond, Th. M.; Beusichem, van,M.L. and Jurkovicova, M. Janessem.1993 .Longterm supply and uptake by plants of elements from coal fly ash. Commun. Soil Sci. Plant Anal. 24 (9 \& 10): 899-913.

[27] Page, A.L.; Elseewi, A.A., Lund, L.J. Bradford, G.R., Mattigod, S., Chang , A.C. and Bingham, F.T. 1980 Consequences of Trace Element Enrichment of Soils and Vegetation from the combustion of Fuels Usedin Power Generation. University of California, Riverside, 158.

[28] Pitchel, J.R. and Hayes,J.M.1990. Influence of fly ash on soil microbial activity and populations. J. Environ. Qual. 19: 593-597.

[29] Rao, D.L.N. and Chhonkar, P.K. 1998. Organic matter in relation to soil biological quality and sustainability. In: T.D. Biswas and G. Narayanaswamy (Eds.) Soil Organic Matter and Organic Residue Management for Sustainable Productivity. Indian Soc. Soil Sci. New Delhi. pp- 80-89.

[30] Roesijadi,G. 1993.Response of invertebrate metallothioneins and MT genes to metals and implications for environmental toxicology. In: K.T. Suzuki ; N. Imura and M. Kimura (Eds). Metallothionein III. Birkhauser Verlag,Basel, Switzerland. pp. 141-158. 
[31] Roy.Gourab; Saha. Abhisek ; Iftikar, Wasim ; Chattopadhyay, G. N and Mandal, B. 2009. Effect of earthworm on recycling of fly ash for agricultural use. Int.Conf.on "Recent trends in lifescience researches vis-à-vis natural resource management, sustainable development and human welfare".June 27-29.2009.Hazaribagh,India.

[32] Saxena, M. and Asokan, P. 2000. Effect of coal ash (NTPC, Rihand Nagar) on soil fertility and various agricultural products. In : Proc. of $2^{\text {nd }}$ Int. Conf. on Fly Ash Disposal and Utilisation (Fly Ash II),2-4 Feb, New Delhi, India, pp-IX-47-62.

[33] Saxena, M.; Murali, S.; Asokan, P.; Mishra, C.R. and pal, H.K 2003. Safe and bulk utilisation of Nalco pond ash in agriculture. . In : Proc. of $3^{\text {rd }}$ Int. Conf. on fly ash disposal and utilisation(Fly Ash II),19-21 Feb, 2003, New Delhi, India, pp-VII-45-53.

[34] Schutter, Macy, E. and Fuhrman, Jeffry 1999 . Microbial responses to coal fly ash under field condition. J. Environ Qual. 28: 648-652.

[35] Senapati, B.K.1993. Earthworms gut content and it's significance. In: A.K.Ghosh (Ed.). Earthworm Resource and Vermiculture, Zoological Survey of India,Calcutta, India, pp-97100.

[36] Sims,J.T. ; Vasilas, B.L. and Ghodrati, M. 1995. Evaluation of fly ash as soil amendment for the Atlantic coastal plain: II Soil chemical properties and crop frowth. J. Water, Soil, Pollut., $81: 363-372$.

[37] Suzuki, K.T., Yamamura, M., Mori, T., 1980. Cadmium-binding proteins induced in the earthworm. Arch. Environ. Contam. Toxicol. 9(4), 415-424.

[38] Tripathi, Prem, S.M.; Singh, Gulab and Tripathi, Ramesh, C. 1997. $1^{\text {st }}$ All India Peoples Technology Congress, Calcutta, India

[39] Venkatesh,R.M. and Eevera, T 2008 Mass reduction and recovery of nutrients through vermicomposting of fly ash. Applied Ecology and Environmental Research 6 (1):77—84.

[40] Wong, J.W.C. and Wong, M.H. 1987. Co-recycling of fly ash and poultry manure in nutrient deficient sandy soil. Resource and Conserv. 13, 291-304. 